\title{
Exploring the Effect of Phyllanthus emblica L. on Cognitive Performance, Brain Antioxidant Markers and Acetylcholinesterase Activity in Rats: Promising Natural Gift for the Mitigation of Alzheimer's Disease
}

\author{
Md. Sahab Uddin ${ }^{a} \quad$ Abdullah Al Mamun ${ }^{a}$ Md. Sarwar Hossain ${ }^{b}$ Farjana Akter ${ }^{b}$ \\ Mohammed Ashraful lqbalc Md. Asaduzzaman ${ }^{\mathrm{a}}$ \\ ${ }^{a}$ Department of Pharmacy, Southeast University, ${ }^{\mathrm{b}}$ Department of Pharmacy, State University of Bangladesh, and \\ 'Department of Chemistry, Fareast International University, Dhaka, Bangladesh
}

\section{Key Words}

Phyllanthus emblica $\cdot$ Cognitive performance $\cdot$ Brain antioxidant markers · Acetylcholinesterase · Alzheimer's disease

\begin{abstract}
Neurodegenerative diseases are incurable and debilitating conditions that result in the progressive degeneration of nerve cells, which affect the cognitive activity. Currently, as a result of multiple studies linking Alzheimer's disease (AD) to oxidative damage, the uses of natural antioxidant to prevent, delay, or enhance the pathological changes underlying the progression of AD has received considerable attention. Therefore, this study was aimed at examining the effect of ethanolic extracts of Phyllanthus emblica (EEPE) ripe (EEPEr) and EEPE unripe (EEPEu) fruits on cognitive functions, brain antioxidant enzymes, and acetylcholinesterase (AChE) activity in rat. The effects of EEPEr and EEPEu fruits (i.e., 100 and $200 \mathrm{mg} / \mathrm{kg}$ b.w.) were examined in Swiss albino male rats for 12 days and its effect on cognitive functions, brain antioxidant enzymes, and AChE activity determined. Learning and memory enhancing activity of EEPE fruit was
\end{abstract}

examined by using passive avoidance test and rewarded alternation test. Antioxidant potentiality was evaluated by measuring the activity of antioxidant enzymes such as superoxide dismutase (SOD), catalase (CAT), glutathione peroxidase (GSH-Px), glutathione reductase, reduced glutathione (GSH), glutathione-S-transferase, and the contents of thiobarbituric acid reactive substances (TBARS) in entire brain tissue homogenates. AChE activity was determined using colorimetric method. Administration of the highest dose (i.e., $200 \mathrm{mg} / \mathrm{kg}$ b.w.) of EEPEr fruit significantly ( $<<$ 0.01 ) and both lowest and highest doses (i.e., 100 and 200 $\mathrm{mg} / \mathrm{kg}$ b.w.) of EEPEu fruit markedly $(\mathrm{p}<0.05, \mathrm{p}<0.001)$ increased step-through latency in rats on 6th, 11 th, and 12th day with respect to the control group. For aforementioned doses, the percentage of memory retention (MR) was considerably $(p<0.05, p<0.01)$ increased in rats on 10th, 11 th, and 12th day with respect to the control group. The extract, particularly highest dose (i.e., $200 \mathrm{mg} / \mathrm{kg}$ b.w.) of EEPEr fruit markedly $(p<0.05)$ and lowest and highest doses (i.e., 100 and $200 \mathrm{mg} / \mathrm{kg}$ b.w.) of EEPEu fruit significantly $(p<0.01)$ increased the correct responses in rats on 6th, and 12th day related to the control group. In case of this test, the percentage of MR was significantly $(p<0.05, p<0.01)$ increased in

\section{KARGER}

E-Mail karger@karger.com

www.karger.com/aon
(C) 2016 S. Karger AG, Basel

$0972-7531 / 16 / 0234-0218 \$ 39.50 / 0$
Md. Sahab Uddin

Department of Pharmacy

Southeast University

Dhaka-1213 (Bangladesh)

E-Mail msu-neuropharma@ hotmail.com 
rats treated with aforementioned doses on 12th day with respect to the control group. The highest dose (i.e., $200 \mathrm{mg} /$ $\mathrm{kg}$ b.w.) of EEPEr fruit suggestively $(\mathrm{p}<0.05)$ and both lowest and highest doses (i.e., 100 and $200 \mathrm{mg} / \mathrm{kg}$ b.w.) of EEPEu fruit suggestively $(p<0.05, p<0.01, p<0.001)$ increased the levels of SOD, CAT, GSH, GSH-Px and expressively $(p<0.01)$ decreased the TBARS level compared to the control group. Treatment with the highest dose (i.e., $200 \mathrm{mg} / \mathrm{kg}$ b.w.) of EEPEr fruit significantly $(\mathrm{p}<0.05)$ and both lowest and highest doses (i.e., 100 and $200 \mathrm{mg} / \mathrm{kg}$ b.w.) of EEPEu fruit markedly ( $p<0.01, p<0.001)$ decreased the level of AChE activity compared to that of the control group. The present study shows that EEPE fruit possesses an excellent source for natural cognitive enhancer which could be developed in the treatment of $A D$ and other neurodegenerative diseases.

(c) 2016 S. Karger AG, Base

\section{Introduction}

Cognitive functions are brain-based superior topographies of human beings that cover all mental functions, mental processes, and states of intelligent entities for processing information, applying wisdom, and changing choice [1]. Memory is a set of programmed neural connections in the brain, to encode, store, and recover information. It is linked, but is different from learning, which is the collection of new information from the surrounding environment [2]. Cognitive impairments have long been known as severe and consistent in some neurological disease conditions such as Alzheimer's disease (AD) [3]. The pathophysiology of this degenerative brain disease is closely connected to the injury and death of neurons that usually starts slowly and gets worse over time [4]. Worldwide, 35 million people are affected by $\mathrm{AD}$, including 5.5 million Americans, and it is projected that in 2050 more than 115 million people will have dementia $[5,6]$.

This disease is characterized by the formation of senile plaques, amyloid- $\beta$ (A $\beta$ ) deposits, and neurofibrillary tangles (NFTs) in the hippocampus and cortex [7]. Senile plaques are spherical collections of dilated, tortuous, dystrophic neuritis around a central amyloid core, microglia and reactive astrocytes at the periphery. Amyloid core is composed of aggregated neurotoxic $A \beta$ (1-42) peptide and a 40- or 42-amino acid peptide [8]. Enzymatic cleavage and improper amyloid precursor protein processing is responsible for the formation of $A \beta$. Deposition of $A \beta$ constitutes the fundamental $\mathrm{AD}$ abnormality. $\mathrm{A} \beta$ peptides are intermediate soluble oligomers that readily ag-

PE L. on Cognitive Performance, Brain Antioxidant Markers and AChE Activity gregate and can be directly synaptotoxic. Aggregates also stimulate an inflammatory response that is blamed for progressive damage through mediator release [9]. NFTs are bundles of paired helical filaments in neuronal cytoplasm, largely containing hyperphosphorylated tau protein as well as ubiquitin and other microtubule-associated molecules [10]. Tau is a microtubule-associated protein that enhances microtubule assembly. Once hyperphosphorylated, it can no longer sustain microtubule assembly, causing disintegration and eventual cell death. In case of senile plaque and NFTs, 4-hydroxy-2-nonenal (HNE) and acrolein are significantly elevated [11]. Patients affected with $\mathrm{AD}$ have higher levels of free HNE in amygdala, hippocampus, and parahippocampal gyrus. An elevation of free HNE levels in ventricular cerebrospinal fluid and serum serves as a biomarker for this disease [12]. HNE may associate with protein and this is observed in 3 stages of $\mathrm{AD}$. In fact association of $\mathrm{HNE}$ with protein serves as an indication of Michael addition of HNE to protein [13]. HNE is responsible for activating the p38 and c-Jun signaling cascades which are responsible for stimulating cellular apoptosis. Research indicates that the accumulation of $A \beta$ in the brain due to oxidative stress is responsible for the formation of senile plaques [14].

Oxidative stress is an important factor in the pathogenesis of $\mathrm{AD}$ [15]. Several studies suggest that $A \beta$ induced neurotoxicity, tau pathology, mitochondria dysfunction, and metal dyshomeostasis seen among Alzheimer patients are due to oxidative stress [16]. Oxidative stress, which facilitates the neurotoxicity initiated by various factors such as abnormal accumulation of $A \beta$ and tau proteins, may increase $A \beta$ production and aggregation in addition to assisting tau phosphorylation and polymerization and further stimulating multiple neurotoxic events such as reactive oxygen species (ROS) production, thereby forming a dangerous cycle that enhances the initiation and progression of AD. Apart from a primary or secondary event, oxidative stress plays a significant role in the development of $\mathrm{AD}[16,17]$. Acetylcholinesterase (AChE) is the primary cholinesterase in the body that plays an important role in the regulation of central cholinergic systems (CCS). In the brain, damage to the CCS due to lack of AChE has been shown to be possibly linked to the memory and cognition deficits associated with $\mathrm{AD}$. In recent times, the drugs available to treat $\mathrm{AD}$ are $\mathrm{AChE}$ inhibitors and N-methyl-D-aspartate receptor antagonist. Currently, 4 reversible AChE inhibitors are approved for the treatment of mild to moderate $\mathrm{AD}$. They are donepezil, galantamine, rivastigmine, and tacrine [18].

Ann Neurosci 2016;23:218-229

DOI: $10.1159 / 000449482$ 
Medicinal plants have been identified and used to treat diseases from ancient times. For the treatment of various minor and major diseases, people of the developing and low income countries depend on medicinal plants [19]. Including Bangladesh, in a number of poor and developing countries, about $80 \%$ people rely on traditional medicines. The use of traditional medicines is not only limited to developing countries, but also to a number of industrialized countries, where many people frequently use several forms of traditional medicines, with England (47\%), Canada (70\%), and Germany (75\%) being examples [20]. WHO stated that more than $80 \%$ of the world's population depends on medicinal plants for their primary healthcare needs [21]. Medicinal plants are the greatest source of natural nootropics. In the treatment of $\mathrm{AD}$, natural nootropics (i.e., smart drugs, memory enhancers, neuro enhancers, cognitive enhancers, and intelligence enhancers) play an important role due to the side effects associated with synthetic learning and memory enhancers such as piracetam and cholinesterase inhibitors [22]. As a result, the search for new natural remedies is ongoing. Ginkgo biloba [23], Bacopa monnieri [24], and Huperzia serrata [25] are well-known natural cognitive enhancers for the treatment of AD.

The plant Phyllanthus emblica (PE) L. is known in Bengali as Amloki and belongs to the Euphorbiaceae family [26]. This plant is indigenous to tropical regions of Southeast Asia. PE is also widely distributed throughout the forests of Chittagong, Chittagong Hill Tracts, Cox's Bazar, Tangail, Dinajpur, Sylhet, and villages of Bangladesh [27]. The fruit of this plant is almost spherical, quite smooth, 18-25 mm wide and 15-20 mm long, light greenish yellow in color, with 6 vertical streaks, and hard in appearance [28]. Traditionally, the fruit is beneficial as an anti-inflammatory, antipyretic, astringent, diuretic, laxative, stomachic, liver, and hair tonic $[29,30]$. This fruit is a great source of numerous phytoconstituents such as alkaloids, flavonoids, terpenoids, tannins, and pectin [31]. The important pharmacological actions of this fruit are antioxidant, analgesic, anti-inflammatory, neuroprotective, antitussive, anti-atherogenic, adaptogenic, cardioprotective, immunomodulatory, gastroprotective, antiviral, antiemetic, anthelmintic, nephroprotective, and anticancer activities [32-35].

Preliminary studies have shown that PE fruit has antioxidant and neuro-enhancing properties [36, 37]. No study has been conducted so far to demonstrate such an effect of PE ripe and unripe fruit that is of benefit in the treatment of AD. Therefore, the purpose of this study was to investigate the effect of ethanolic extract of PE (EEPE) ripe (EEPEr) and EEPE unripe (EEPEu) fruits on learning and memory improvement in rats by behavioral tests such as passive avoidance (PA) test, rewarded alternation (RA) test, and the activity of brain antioxidant enzymes by biochemical tests such as superoxide dismutase (SOD), catalase (CAT), glutathione peroxidase (GSH-Px), glutathione reductase (GSR), reduced glutathione (GSH), glutathione-S-transferase (GST), estimation of contents of thiobarbituric acid (TBA) reactive substances (TBARS), and $\mathrm{AChE}$ activity in rat brain tissue homogenates.

\section{Materials and Methods}

\section{Chemicals and Drug}

Acetyl thiocholine iodide (ATCI), 5,5-dithiobis-2-nitrobenzoate ion (DTNB), tris amino methane hydrochloride (Tris- $\mathrm{HCl}$ ), bovine serum albumin (BSA), phenazine methosulphate, sulfosalicylic acid, sodium pyrophosphate, sodium azide, GSR, GSH, oxidized glutathione, reduced GSH, ethylenediaminetetraacetic acid (EDTA), nicotinamide adenine dinucleotide phosphate (NADPH), 1-chloro-2,4-dinitrobenzene (CDNB), TBA, and trichloroacetic acid (TCA) all were purchased from Sigma-Aldrich, USA. All other chemicals were of analytical grade, unless otherwise specified and purchased from indigenous sources. Donepezil hydrochloride powder was obtained from Incepta Pharmaceuticals Ltd., Dhaka, Bangladesh, as gift.

\section{Collection and Identification of Plant Materials}

The fresh leaves of PE were collected from Sitakunda Upazila under the Chittagong district, Bangladesh, in October 2015, and identified by an expert taxonomist from the Bangladesh National Herbarium, Mirpur, Dhaka, Bangladesh. A voucher specimen was preserved in the herbarium for future reference. Accession number: DACB-42531 for PE.

\section{Drying and Grinding of Plant Materials}

The fresh ripe and unripe fruits of the plant were collected (weighing each $5 \mathrm{~kg}$ ), washed properly to remove dirt and shade dried for $30 \mathrm{~min}$. Then seeds were separated from the fruits and shade dried for 7 days with irregular sun drying. These dried fruits were then dried in an oven for $24 \mathrm{~h}$ at considerably lower temperatures for better grinding. The dried fruits were milled separately into coarse powder by using a grinding machine and kept in an airtight container for extraction.

\section{Extraction of Plant Materials}

Each powdered plant material (fruits), having a weight of $500 \mathrm{~g}$, was taken in an amber colored glass bottle and soaked in 2.5 liter of $98 \%$ ethanol. The bottle with its contents was sealed and kept at room temperature and allowed to stand for 7 days with irregular shaking. Then the extracts were filtered through cotton and then through Whatman (No. 1) filter paper. The liquid filtrates were concentrated and evaporated to dry at $50^{\circ} \mathrm{C}$ temperature by using a rotary evaporator under reduced pressure to get the crude extract (12.35 g for EEPEr and $10.62 \mathrm{~g}$ for EEPEu fruit). Finally, dried crude ethanolic extracts were stored at $4^{\circ} \mathrm{C}$ for further tests. 
Animals

All experiments were carried out using 46 healthy adult male, Swiss albino rats weighing about 190-180 g purchased from ICDDR,B, Dhaka, Bangladesh. The rats were housed in 6 per animal cage and placed under standard environmental conditions $\left(25 \pm 2{ }^{\circ} \mathrm{C}\right.$ temperature, $60 \pm 5 \%$ relative humidity) with a half day light and dark cycle. Standard laboratory food and water were administered properly. The care and use of the animals were monitored along with the guide for laboratory animals of the National Institutes of Health (NIH) [38]. The protocol of the experiment was approved by the Animal Ethics Committee of the Department of Pharmacy, Southeast University, Dhaka, Bangladesh.

\section{Administration of Drugs and Test Compounds}

A solution of donepezil hydrochloride was prepared by using normal saline having $\mathrm{pH} 7.4$ and administered orally to experimental rats at $1 \mathrm{mg} / \mathrm{kg}$ body weight (b.w.). Weighed quantity of EEPE was suspended in normal saline ( $\mathrm{pH} 7.4)$ and administered orally to rats at 100 and $200 \mathrm{mg} / \mathrm{kg}$ b.w. The duration of the study and doses of donepezil hydrochloride and EEPE were adjusted based on literature searches $[39,40]$. Every day, standard drug and the suspension of extract were prepared freshly and administered before $30 \mathrm{~min}$ of the experiment.

\section{Experimental Design}

Rats were divided randomly into 6 groups as follows:

Group 1: standard food and water were administered for 12 days to rats (Con),

Group 2: donepezil hydrochloride at a dose of $1 \mathrm{mg} / \mathrm{kg}$ b.w. was administered orally for 12 days to rats (Don),

Group 3: ripe fruit extract at a dose of $100 \mathrm{mg} / \mathrm{kg}$ b.w. was administered orally for 12 days to rats (EEPEr 100),

Group 4: unripe fruit extract at a dose of $100 \mathrm{mg} / \mathrm{kg}$ b.w. was administered orally for 12 days to rats (EEPEu 100),

Group 5: ripe fruit extract at a dose of $200 \mathrm{mg} / \mathrm{kg}$ b.w. was administered orally for 12 days to rats (EEPEr 200),

Group 6: unripe fruit extract at a dose of $200 \mathrm{mg} / \mathrm{kg}$ b.w. was administered orally for 12 days to rats (EEPEu 200).

\section{Acute Toxicity Study}

The acute oral toxicity test of the EEPE was performed according to the Organization for Economic Cooperation and Development guidelines in healthy male Swiss albino rats [41]. For this test, rats were arbitrarily divided into 6 groups with 6 animals in each group, and normal saline was used to prepare the suspension of the extract. The rats were kept on fasting for 3-4 h with supplementation of water prior to oral dosing. Then the extract was administered orally at different dose levels (i.e., 25, 50, 100, 500, 1,000, and $2,000 \mathrm{mg} / \mathrm{kg}$ b.w.) with the help of intragastric tube. After dose administration, food was withdrawn for $1-2 \mathrm{~h}$. The rats were observed uninterruptedly for next $24 \mathrm{~h}$ for behavioral change, any adverse change and subsequently 14 days for any lethality and death.

\section{Behavioral Study}

One week training was conducted to prepare rats for behavioral study. During the training period, they received only food and water. The completely trained rats were selected for the study. Behavioral studies were conducted between 10.00 a.m. and 3.00 p.m. in a sound resistant room.

PE L. on Cognitive Performance, Brain Antioxidant Markers and AChE Activity

\section{PA Test}

The sensitive memory of rats based on contextual fear conditioning learning and instrumental learning was assessed by using the PA test [42], which consists of light and dark compartments, each measuring 270 (depth) $\times 370$ (width) $\times 360$ (height) $\mathrm{mm}$. The light compartment and the dark compartment were made by transparent and black vinyl chloride plates, respectively. The 2 compartments of this apparatus were connected by a sliding door having $90 \mathrm{~mm}$ diameter in the middle part. The floor of this apparatus consisted of a metal grid spaced $0.9 \mathrm{~cm}$ apart and connected to a shock generator, able to generate shock in the range of $0.5 \mathrm{~mA}$. Lighting in the light compartment was provided by fluorescent lamp [43]. Each test consists of 2 distinct trials such as acquisition trial and retention trial. For the acquisition trial, each rat was placed in the light compartment in front of the wall opposite to the sliding door. After adaptation for $15 \mathrm{~s}$, the sliding door was opened and when the rat entered into the dark compartment, an electrical foot shock of $0.5 \mathrm{~mA}$ was administered for $3 \mathrm{~s}$ [44]. The latency times, once the rat had entered the dark compartment was recorded as initial transfer latency (ITL) with the help of stopwatch. Subsequently, the rat was returned to its home cage. A retention trial was performed after $24 \mathrm{~h}$ of the acquisition trial, in which no shock was given when the rat entered the dark compartment and latency times to re-enter the dark chamber were measured as stepthrough latency (STL) up to $300 \mathrm{~s}$ [45]. After the determination of ITL on 5th and 9th days, STL was measured on 6th and 10th day (i.e., $24 \mathrm{~h}$ later in the acquisition trial), yet again STL was determined on 11 th and 12 th day (i.e., $48,72 \mathrm{~h}$ later in the acquisition trial), respectively to determine the long-term memory. The percent of memory retention (MR) was calculated by using the formula given below:

$$
\% \mathrm{MR}=(\mathrm{STL}-\mathrm{ITL}) / \mathrm{ITL} \times 100
$$

An increase in percentage of MR directed enhanced retention of memory [46]. The apparatus was cleaned after each test with $70 \%$ ethanol to avoid instinctive odorant clues [47].

\section{RA Test}

The spatial working memory of rats was assessed by using the RA test [48], which consists of 3 identical arms, each measuring 500 (length) $\times 100$ (width) $\times 100$ (height of the side walls) $\mathrm{mm}$. The arms were connected by a central square in the middle of the maze to form a T-shape. These 3 arms were designated as start arm, force arm, and novel arm. Each day, each rat was subjected to 6 trials, and each test consisted of 2 distinct trials, forced run trial, and choice run trial. For the forced run trial, the novel arm was blocked and each rat was placed in the start arm facing the central square and forced to the force arm to consume the pellet placed previously. Subsequently, the rat was returned to its home cage. A choice run trial was performed after $60 \mathrm{~s}$ of the forced run trial, in which the novel arm was opened (i.e., both the arms were free for the rat to choose). In this choice run trial, the force arm was kept empty and pellets were placed in the novel arm. During the choice run trial, if the rat entered into the novel arm, then the response was considered as correct response (CR). If it entered into the force arm, then it was considered a wrong response (WR) $[49,50]$. The number of CR and 
WR were measured on 6th and 12th day. The percentage of MR (i.e., learned task) was calculated by using the formula given below:

$$
\% \mathrm{MR}=\mathrm{TCRs} \times 100 / \mathrm{TTs}
$$

where TCRs $=$ total number of CRs, TTs $=$ total number of trials. An increase in percentage of MR was considered as an index of improved cognition (i.e., learning and memory) $[49,50]$. The apparatus was cleaned after each test with $70 \%$ ethanol to avoid instinctive odorant clues [47].

\section{Biochemical Study}

The rats were sacrificed under light anesthesia on 13th day by cervical decapitation, and the whole brain was collected and placed on an ice-chilled petri dish for cleaning. The cerebellum was rapidly removed from the whole brain tissue and the remaining brain was rinsed with ice-cold $0.9 \% \mathrm{NaCl}$ and finally each hemisphere was separated. One of the 2 hemispheres was used to prepare $10 \%$ brain homogenate by using ice-cold $30 \mathrm{mM}$ $\mathrm{Na}_{2} \mathrm{HPO}_{4}$, pH 7.6 in a homogenizer. Then the homogenate was centrifuged at $20,000 \mathrm{rpm}$ for $2 \mathrm{~h}$ at $4^{\circ} \mathrm{C}$ to remove cellular debris, and the supernatant was used for the determination of SOD, CAT, GSH-Px, GSH, GSH, GST, and TBARS activities. Remaining hemispheres were homogenized $(10 \% \mathrm{w} / \mathrm{v})$ with a glass homogenizer in ice-cold $30 \mathrm{mM} \mathrm{Na}_{2} \mathrm{HPO}_{4}, \mathrm{pH} 7.6$ and centrifuged at $20,000 \mathrm{rpm}$ for $2 \mathrm{~h}$ at $4^{\circ} \mathrm{C}$ to obtain the salt soluble (SS) part. The pellets were re-extracted with an equal volume of ice-cold phosphate buffer containing $1 \%$ Triton X-100 and centrifuged at $20,000 \mathrm{rpm}$ for $2 \mathrm{~h}$ at $4^{\circ} \mathrm{C}$ to recover the detergent soluble (DS) part [45]. Supernatant obtained from both extraction procedures were stored at $-20^{\circ} \mathrm{C}$ and used for AChE activity. The protein concentration was determined by using BSA [51].

\section{SOD Assay}

The method of Kakkar et al. [52] was used for the determination of the SOD activity. The total volume of the reaction mixture for this test was $1.6 \mathrm{ml}$; it consisted of $0.1 \mathrm{ml}$ of $186 \mu \mathrm{M}$ phenazine methosulphate, $1.2 \mathrm{ml}$ of $0.052 \mathrm{~mm}$ sodium pyrophosphate buffer having $\mathrm{pH} 7.0$, and $0.3 \mathrm{ml}$ of supernatant after centrifugation $(1,500 \mathrm{~g}, 10 \mathrm{~min}$ followed by $10,000 \mathrm{~g}, 15 \mathrm{~min})$ of $10 \%$ brain tissue homogenate. To start the enzyme reaction, $0.2 \mathrm{ml}$ of $780 \mu \mathrm{M}$ NADPH was added to the reaction mixture. After 1 min incubation, enzyme reaction was stopped by adding $1 \mathrm{ml}$ of glacial acetic acid. The changes in absorbance of the reaction mixture were determined at $560 \mathrm{~nm}$ by using spectrophotometer and expressed as $\mathrm{U} / \mathrm{mg}$ protein.

\section{CAT Assay}

The method of Chance and Maehly with some modification was used for the determination of the CAT activity [53]. The total volume of the reaction mixture for this test was $3.0 \mathrm{ml}$; it consisted of $2.5 \mathrm{ml}$ of $50 \mathrm{mM}$ phosphate buffer having $\mathrm{pH} 5.0,0.4 \mathrm{ml}$ of 5.9 $\mathrm{mM} \mathrm{H}_{2} \mathrm{O}_{2}$, and $0.1 \mathrm{ml}$ of $10 \%$ brain tissue homogenate. After $1 \mathrm{~min}$ incubation, the changes in absorbance of the reaction mixture were determined at $240 \mathrm{~nm}$ by using spectrophotometer. Here one unit of CAT activity was defined as an absorbance change of 0.01 and expressed as $\mathrm{U} / \mathrm{min}$.

\section{GSR Assay}

The method of Carlberg and Mannervik was used for the determination of the GSR activity [54]. The total volume of the reaction mixture was $2.0 \mathrm{ml}$; it consisted of $1.65 \mathrm{ml}$ of $0.1 \mathrm{M}$ phosphate buffer having $\mathrm{pH} 7.6,0.1 \mathrm{ml}$ of $0.5 \mathrm{mM}$ EDTA, $0.1 \mathrm{ml}$ of $0.1 \mathrm{mM}$ NADPH, $0.05 \mathrm{ml}$ of $1 \mathrm{mM}$ oxidized GSH, and $0.1 \mathrm{ml}$ of $10 \%$ brain tissue homogenate. The changes in absorbance of the reaction mixture, that is, disappearance of $\mathrm{NADPH}$ at $25^{\circ} \mathrm{C}$ were determined at $340 \mathrm{~nm}$ by using spectrophotometer and expressed as $\mathrm{nM}$ $\mathrm{NADPH}$ oxidized $/ \mathrm{min} / \mathrm{mg}$ protein using a molar extinction coefficient of $6.22 \times 10^{3} \mathrm{M}^{-1} \mathrm{~cm}^{-1}$.

\section{GSH Assay}

The method of Jollow et al. [56] was used for the determination of the GSH activity. For this test, $1.0 \mathrm{ml}$ of $10 \%$ brain tissue homogenate was precipitated with $1.0 \mathrm{ml}$ of $4 \%$ sulfosalicylic acid. The samples were kept at $4^{\circ} \mathrm{C}$ for $1 \mathrm{~h}$ and then centrifuged $(1,200 \mathrm{~g}$ for $20 \mathrm{~min}$ ) at $4^{\circ} \mathrm{C}$. The total volume of the reaction mixture was 3.0 $\mathrm{ml}$; it consisted of $0.1 \mathrm{ml}$ filtered aliquot, $2.7 \mathrm{ml}$ of $0.1 \mathrm{M}$ phosphate

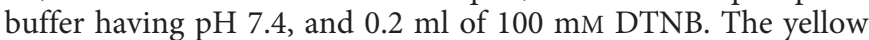
color of the mixture was developed and the absorbance of the reaction mixture was determined at $412 \mathrm{~nm}$ by using spectrophotometer and expressed as $\mu \mathrm{M} \mathrm{GSH/g}$ protein.

\section{GST Assay}

The method of Habig et al. [57] was used for the determination of the GST activity. The total volume of the reaction mixture was $2.0 \mathrm{ml}$; it consisted of $1.475 \mathrm{ml}$ of $0.1 \mathrm{M}$ phosphate buffer having $\mathrm{pH} 6.5,0.025 \mathrm{ml}$ of $1 \mathrm{~mm}$ CDNB, $0.2 \mathrm{ml}$ of $1 \mathrm{~mm}$ reduced GSH, and $0.3 \mathrm{ml}$ of $10 \%$ brain tissue homogenate. The changes in absorbance of the reaction mixture were determined at $340 \mathrm{~nm}$ by using spectrophotometer and expressed as nM CDNB conjugate formed/ $\mathrm{min} / \mathrm{mg}$ protein using a molar extinction coefficient of $9.6 \times 10^{3}$ $\mathrm{M}^{-1} \mathrm{~cm}^{-1}$.

\section{GSH-Px Assay}

The method of Mohandas et al. [54] was used for the determination of the GSH-Px activity. The total volume of the reaction mixture for this test was $2.0 \mathrm{ml}$; it consisted of $1.49 \mathrm{ml}$ of $0.1 \mathrm{M}$ phosphate buffer having $\mathrm{pH} 7.4,0.1 \mathrm{ml}$ of $1 \mathrm{mM}$ sodium azide, 0.05 $\mathrm{ml}$ of $1 \mathrm{IU} / \mathrm{ml} \mathrm{GSR}, 0.05 \mathrm{ml}$ of $1 \mathrm{mM}$ GSH, $0.1 \mathrm{ml}$ of $1 \mathrm{mM}$ EDTA, $0.1 \mathrm{ml}$ of $0.2 \mathrm{mM} \mathrm{NADPH}, 0.01 \mathrm{ml}$ of $0.25 \mathrm{mM} \mathrm{H}_{2} \mathrm{O}_{2}$, and $0.1 \mathrm{ml}$ of $10 \%$ brain tissue homogenate. The changes in absorbance of the reaction mixture, that is, disappearance of NADPH at $25^{\circ} \mathrm{C}$ were determined at $340 \mathrm{~nm}$ by using spectrophotometer and expressed as nM NADPH oxidized $/ \mathrm{min} / \mathrm{mg}$ protein using a molar extinction coefficient of $6.22 \times 10^{3} \mathrm{M}^{-1} \mathrm{~cm}^{-1}$.

\section{Lipid Peroxidation (TBARS) Assay}

The method of Iqbal et al. [58] was used for the determination of the TBARS activity. The total volume of the reaction mixture was $1.0 \mathrm{ml}$; it consisted of $0.58 \mathrm{ml}$ of $0.1 \mathrm{M}$ phosphate buffer having $\mathrm{pH} 7.4,0.2 \mathrm{ml}$ of $100 \mathrm{mM}$ ascorbic acid, $0.02 \mathrm{ml}$ of $100 \mathrm{mM}$ ferric chloride, and $0.2 \mathrm{ml}$ of $10 \%$ brain tissue homogenate. The reaction mixture was incubated at $37^{\circ} \mathrm{C}$ in a shaking water bath for $1 \mathrm{~h}$. Then $1.0 \mathrm{ml}$ of $10 \%$ TCA was added to stop the reaction. Following the addition of $1.0 \mathrm{ml} 0.67 \% \mathrm{TBA}$, all the test tubes were boiled in a water bath for $20 \mathrm{~min}$. Then the test tubes were shifted to crushed ice bath before centrifuging (2,500 $\mathrm{g}$ for $10 \mathrm{~min})$. The amount of TBARS formed in each of the samples was determined by measur- 
ing the optical density of the supernatant at $535 \mathrm{~nm}$ by using spectrophotometer against a reagent blank and expressed as nM TBARS $/ \mathrm{min} / \mathrm{mg}$ protein at $37^{\circ} \mathrm{C}$ using a molar extinction coefficient of $1.56 \times 10^{5} \mathrm{M}^{-1} \mathrm{~cm}^{-1}$.

\section{AChE Assay}

The method of Ellman et al. [59] was used for the determination of the AChE activity. For this test, $25 \mu \mathrm{l}$ of $15 \mathrm{mM}$ ATCI, $75 \mu \mathrm{l}$ of $3 \mathrm{~mm}$ DTNB, and $75 \mu \mathrm{l}$ of $50 \mathrm{~mm}$ Tris- $\mathrm{HCl}$ having $\mathrm{pH}$ 8.0, containing $0.1 \%$ BSA were added in the 96 well plates and incubated for $5 \mathrm{~min}$ at $25^{\circ} \mathrm{C}$. Then absorbance was determined at $405 \mathrm{~nm}$ by using spectrophotometer. Any increase in the absorbance owing to the regular hydrolysis of the substrate was adjusted by subtracting the rate of the reaction before adding the enzyme. Then $25 \mu \mathrm{l}$ of brain tissue homogenates (SS and DS portion) were added and the absorbance was determined again after incubation for $5 \mathrm{~min}$ at $25^{\circ} \mathrm{C}$. The AChE activity was expressed as $\mathrm{M} / \mathrm{min} / \mathrm{g}$ protein.

\section{Statistical Analysis}

Results were presented as mean \pm SEM and analyzed with oneway analysis of variance. Tukey's post-hoc test was performed for behavioral studies and in case of biochemical studies the least significant difference was determined using post-hoc testing for inter group comparisons at a probability level of 0.05 and $0.01 \%$. SPSS 14.0 (Chicago, Ill., USA) and Microsoft Excel 2010 (Roselle, Ill., USA) were used for the statistical and graphical evaluations. The results were considered as statistically significant at $\mathrm{p}<0.05$ compared to the control group.

\section{Results}

\section{Determination of Acute Toxicity}

Oral administration of EEPE was shown to be safe up to the dose level of $2,000 \mathrm{mg} / \mathrm{kg}$ b.w. in rats. In any rat, the extracts did not influence any toxicological effect. During the experimental stage, any change in behavioral, motor, and neuronal functions and mortality were not claimed in addition to the monitoring of skin, fur, and eyes of the rats that remained constant so that the extracts were considered safe.

\section{Effect of EEPE on Learning and Memory of Rats Using PA Test}

Effect of EEPE on ITL and STL of rats is shown in figures 1 and 2. The rats treated with EEPEr and EEPEu fruits (i.e., 100 and $200 \mathrm{mg} / \mathrm{kg}$, b.w.) and donepezil hydrochloride showed dose-dependent alteration of ITL and STL. The highest dose (i.e., $200 \mathrm{mg} / \mathrm{kg}$ b.w.) of EEPEr fruit considerably $(\mathrm{p}<0.01)$ increased STL in rats on 11th day as compared to the control group. For EEPEu fruit, both lowest and highest doses (i.e., 100 and $200 \mathrm{mg} / \mathrm{kg}$ b.w.) significantly $(\mathrm{p}<0.05, \mathrm{p}<0.001)$ increased the STL of rats on 6th and 12th day with respect to the control

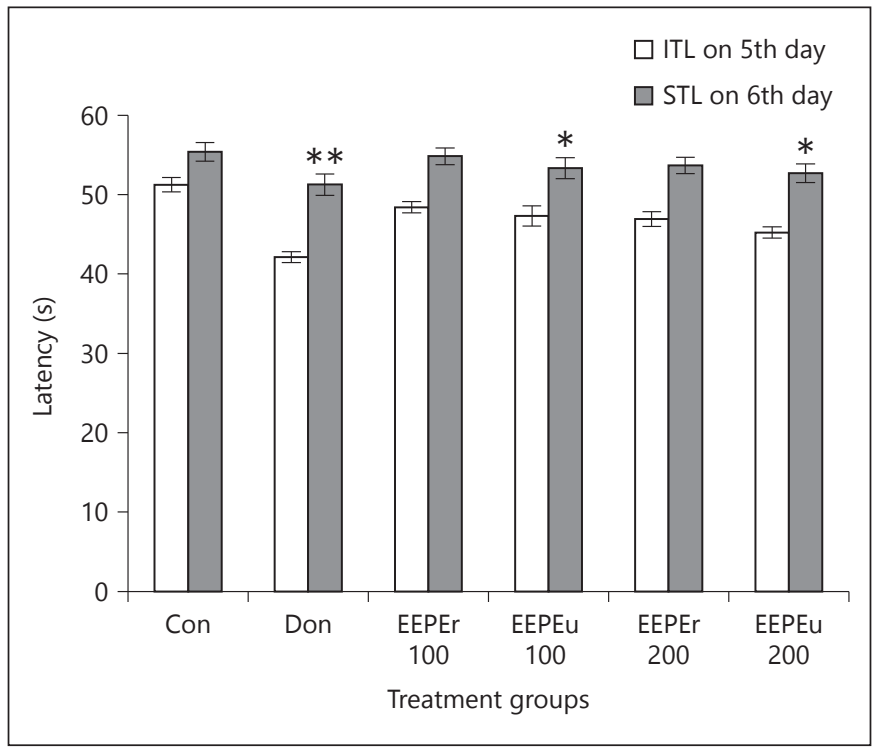

Fig. 1. Effect of EEPE on ITL and STL of rats on 5th and 6th day using PA test. Values were expressed as mean \pm SEM ( $n=6$ /group). ${ }^{*} \mathrm{p}<0.05,{ }^{* *} \mathrm{p}<0.01$ significant difference from the control group.

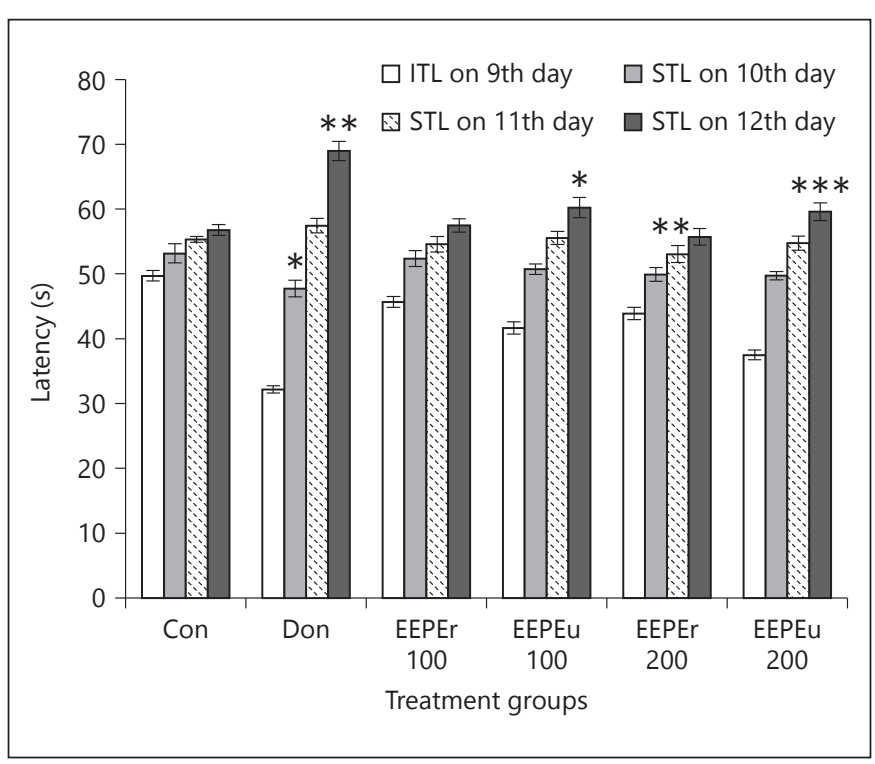

Fig. 2. Effect of EEPE on ITL and STL of rats on 9th and 10th, 11th and 12th day using PA test. Values were expressed as mean \pm SEM ( $\mathrm{n}=6$ /group). ${ }^{*} \mathrm{p}<0.05,{ }^{* *} \mathrm{p}<0.01,{ }^{* * *} \mathrm{p}<0.001$ significant difference from the control group.

group. For all extract treated groups, the value of STL was greater on 11th and 12th day, respectively, than the 10th day STL. The rats treated with donepezil hydrochloride showed significant $(\mathrm{p}<0.05, \mathrm{p}<0.01)$ increase in STL on successive days compared to the control group. Figure 3 


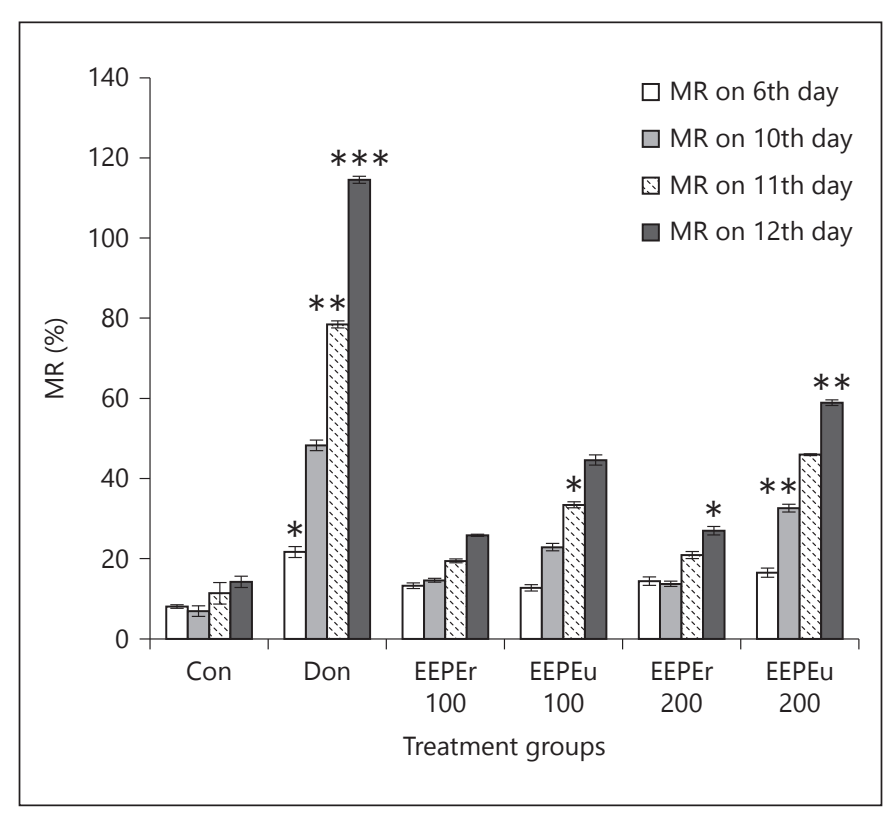

Fig. 3. Effect of EEPE on the percentage of $M R$ of rats using $P A$ test. Values were expressed as mean \pm SEM $\left(n=6 /\right.$ group). ${ }^{*} \mathrm{p}<$ $0.05,{ }^{* *} \mathrm{p}<0.01,{ }^{* * *} \mathrm{p}<0.001$ significant difference from the control group.

presented the percentage of MR of rats in which an increase in MR after 24, 48, and $72 \mathrm{~h}$, respectively, indicated improved retention of learning task. The percentage of MR was significantly $(\mathrm{p}<0.05, \mathrm{p}<0.01)$ increased in rats treated with highest dose (i.e., $200 \mathrm{mg} / \mathrm{kg}$ b.w.) of EEPEr fruit and both lowest and highest doses (i.e., 100 and 200 $\mathrm{mg} / \mathrm{kg}$ b.w.) of EEPEu fruit on 10th, 11th, and 12th day as compared to the control group.

\section{Effect of EEPE on Learning and Memory of Rats Using RA Test}

Figure 4 shows the results of the RA test in which the EEPE fruit showed a dose-dependent increase in the number of CR of rats as compared to the control group. Donepezil hydrochloride treated group showed marked $(\mathrm{p}<0.05, \mathrm{p}<0.01)$ increases in the number of CR on 6 th and 12th day with respect to the control group. The rats treated with the highest dose (i.e., $200 \mathrm{mg} / \mathrm{kg}$, b.w.) of EEPEr fruit significantly $(\mathrm{p}<0.05)$ increased the CR on 12 th day as compared to the control group. In fact, the lowest and highest doses (i.e., 100 and $200 \mathrm{mg} / \mathrm{kg} \mathrm{b.w.)} \mathrm{of}$ EEPEu fruit showed noticeable $(\mathrm{p}<0.01)$ activity on 12 th day. Percentage of MR of rats is given in figure 5 , in which an increase in MR indicated improved learning and memory. The rats treated with highest dose (i.e., $200 \mathrm{mg} /$ $\mathrm{kg}$ b.w.) of EEPEr fruit and both lowest and highest doses

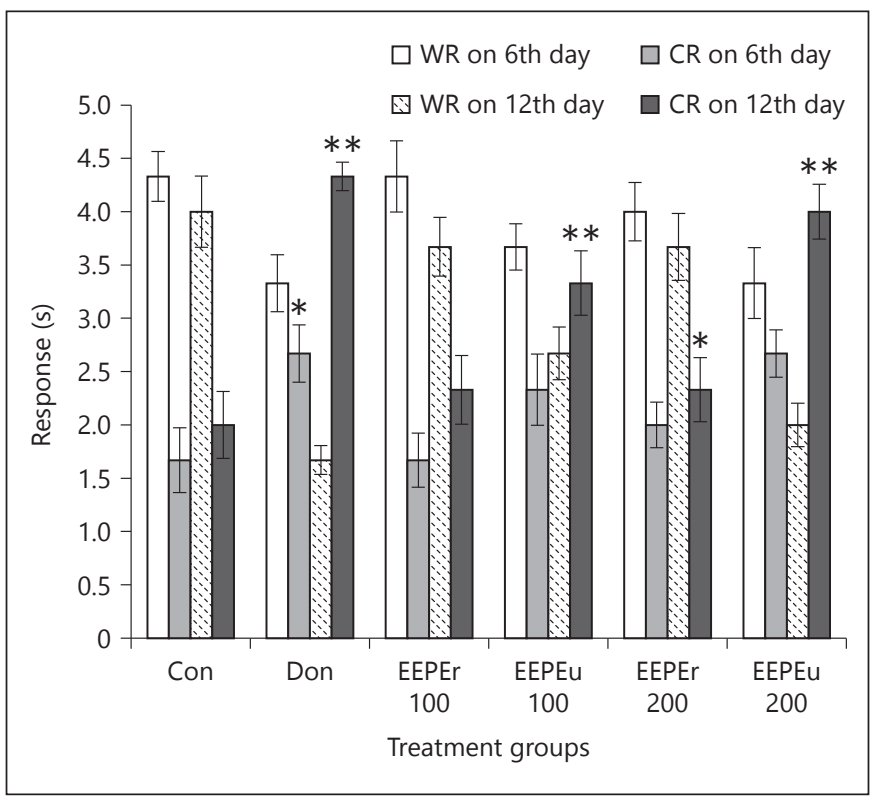

Fig. 4. Effect of EEPE on WR and CR of rats using RA test. Values were expressed as mean \pm SEM ( $n=6 /$ group). ${ }^{*} \mathrm{p}<0.05,{ }^{* *} \mathrm{p}<$ 0.01 significant difference from the control group.

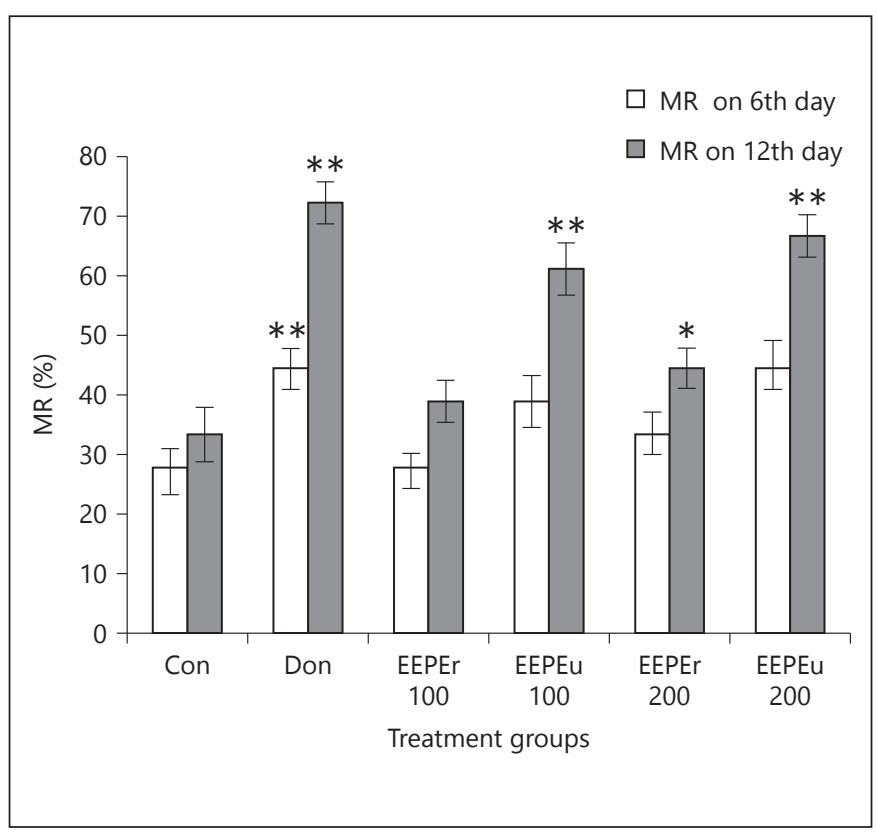

Fig. 5. Effect of EEPE on percentage of MR of rats using RA test. Values were expressed as mean \pm SEM ( $n=6$ /group). ${ }^{*} \mathrm{p}<0.05$, ${ }^{* *} \mathrm{p}<0.01$ significant difference from the control group. 
Table 1. Effect of EEPE on biochemical parameters of rat brain antioxidant defense system

\begin{tabular}{|c|c|c|c|c|c|c|c|}
\hline Treatment & $\begin{array}{l}\mathrm{SOD}, \mathrm{U} / \mathrm{mg} \\
\text { protein }\end{array}$ & $\mathrm{CAT}, \mathrm{U} / \mathrm{min}$ & $\begin{array}{l}\mathrm{GSR}, \mathrm{nM} / \mathrm{min} / \\
\mathrm{mg} \text { protein }\end{array}$ & $\begin{array}{l}\mathrm{GSH}, \mu \mathrm{M} / \mathrm{g} \\
\text { protein }\end{array}$ & $\begin{array}{l}\mathrm{GST}, \mathrm{nM} / \mathrm{min} / \\
\mathrm{mg} \text { protein }\end{array}$ & $\begin{array}{l}\text { GSH-Px, nM/ } \\
\mathrm{min} / \mathrm{mg} \text { protein }\end{array}$ & $\begin{array}{l}\text { TBARS, nM/ } \\
\text { min/mg protein }\end{array}$ \\
\hline Con & $10.17 \pm 1.20$ & $8.07 \pm 0.83$ & $126.42 \pm 4.48$ & $50.69 \pm 7.42$ & $102.49 \pm 4.40$ & $27.32 \pm 1.41$ & $190.71 \pm 3.49$ \\
\hline EEPEr 100 & $11.40 \pm 1.23$ & $10.45 \pm 0.42$ & $130.64 \pm 3.89$ & $63.77 \pm 3.53$ & $113.27 \pm 7.54$ & $30.55 \pm 4.62$ & $179.05 \pm 4.62$ \\
\hline EEPEu 100 & $12.93 \pm 1.01^{*}$ & $14.78 \pm 0.87^{*}$ & $167.14 \pm 1.06$ & $74.00 \pm 8.22^{* *}$ & $131.82 \pm 2.75$ & $35.23 \pm 1.29$ & $164.47 \pm 3.56^{* *}$ \\
\hline EEPEr 200 & $13.05 \pm 0.70$ & $12.26 \pm 1.68^{*}$ & $145.47 \pm 5.74$ & $79.54 \pm 2.83$ & $117.05 \pm 5.56^{*}$ & $32.88 \pm 4.63$ & $172.52 \pm 4.32^{*}$ \\
\hline
\end{tabular}

The rats brain biochemical parameters were expressed as mean \pm SEM values ( $n=6 /$ group).

${ }^{*} \mathrm{p}<0.05,{ }^{* *} \mathrm{p}<0.01,{ }^{* * *} \mathrm{p}<0.001$ significant difference from the control group.

(i.e., 100 and $200 \mathrm{mg} / \mathrm{kg}$ b.w.) of EEPEu fruit showed considerably ( $\mathrm{p}<0.05, \mathrm{p}<0.01)$ increased percentage of MR on 12th day as compared to the control group.

\section{Effect of EEPE on Brain Oxidative Status}

Alteration of antioxidant enzyme activities in rat's brain tissue homogenates is displayed in table 1. Administration of EEPEr and EEPEu fruits and donepezil hydrochloride significantly altered the activities of SOD, CAT, GSH-Px, GSR, GSH, GST, and TBARS in a dosedependent way. EEPEr fruit at $200 \mathrm{mg} / \mathrm{kg}$ b.w. considerably $(\mathrm{p}<0.05)$ increased the level of CAT and GST, while markedly $(\mathrm{p}<0.05)$ reduced the concentration of TBARS to that of the control group. For EEPEu fruit (i.e., 100 and $200 \mathrm{mg} / \mathrm{kg}$ b.w.), significantly ( $<<0.05, \mathrm{p}<0.01$, $\mathrm{p}<$ 0.001 ) increased concentration of SOD, CAT, GSH, GSHPx and markedly $(\mathrm{p}<0.01)$ reduced concentration of TBARS was detected as compared to the control group. In case of donepezil-treated rats, significant $(\mathrm{p}<0.05, \mathrm{p}<$ 0.01 ) increase in the level of CAT, GSR, GSH, GSH-Px and noticeable $(\mathrm{p}<0.01)$ decrease in the level of TBARS were reported.

\section{Effect of EEPE on Brain AChE Activity}

The activity of AChE in the SS and DS portions of rat brain tissue homogenate is given in table 2 . Treatment with EEPEr and EEPEu fruits and donepezil hydrochloride extensively decreases the concentration of AChE level in a dose-dependent manner. Donepezil treatment substantially $(\mathrm{p}<0.01)$ decreased the AChE level in both SS and DS portions of rat's brain tissue homogenate compared to the control group. EEPEr fruit at concentration of $200 \mathrm{mg} / \mathrm{kg}$ b.w. noticeably $(\mathrm{p}<0.05)$ decreased the AChE activity in SS brain tissue homogenate of rats with respect to the control group. Administration of lowest
Table 2. Effect of EEPE on AChE activity in rat brain

\begin{tabular}{lll}
\hline Treatment & $\begin{array}{l}\text { SS AchE, M/min/g } \\
\text { protein }\end{array}$ & $\begin{array}{l}\text { DS AchE, M/min/g } \\
\text { protein }\end{array}$ \\
\hline Con & $0.183 \pm 0.002$ & $0.905 \pm 0.021$ \\
Don & $0.102 \pm 0.002^{* *}$ & $0.323 \pm 0.010^{* *}$ \\
EEPEr 100 & $0.165 \pm 0.003$ & $0.746 \pm 0.021$ \\
EEPEu 100 & $0.126 \pm 0.004^{* *}$ & $0.479 \pm 0.013$ \\
EEPEr 200 & $0.141 \pm 0.003^{*}$ & $0.531 \pm 0.015$ \\
EEPEu 200 & $0.110 \pm 0.003^{* *}$ & $0.395 \pm 0.011^{* * *}$ \\
\hline
\end{tabular}

The AChE activity for each group was expressed as mean \pm SEM values ( $\mathrm{n}=6$ /group).

${ }^{*} \mathrm{p}<0.05,{ }^{* *} \mathrm{p}<0.01,{ }^{* * *} \mathrm{p}<0.001$ significant difference from the control group.

and highest doses (i.e., 100 and $200 \mathrm{mg} / \mathrm{kg}$ b.w.) of EEPEu fruit suggestively $(\mathrm{p}<0.01, \mathrm{p}<0.001)$ decreases the AChE activity in both SS and DS portions of brain tissue homogenate of rats as compared to the control group.

\section{Discussion}

Medicinal plants are rich sources of phytochemicals, which have a significant role in the treatment of various diseases [60]. The phytoconstituents of medicinal plants play an important role in the treatment of cognitive impairment associated with aging and neurodegenerative disorder [61]. Natural nootropic plants such as Ginkgo biloba, Bacopa monnieri, and Huperzia serrata has been extensively examined for their anti-Alzheimer effect [62]. In this study, EEPEr and EEPEu fruits was administered for 12 days showed momentous memory enhancing effect in rats. 
This is the first experiment showing memory enhancing activity of EEPEr and EEPEu fruits in rats. In PA test, neuronal activity (i.e., emotional memory) of rats was examined in which ITL and STL were the measured parameters. STL is the measure of memory in rats after an aversive stimulus. In this test, an increase in STL on 6th (after $24 \mathrm{~h}$ of ITL), 10th, 11th, and 12th day (after 24, 48 and 72 h of ITL) after the ITL on 5th and 9th day, respectively, indicated improvement of learning and memory of rats with respect to the control group. Percentage of MR was also determined that indicate strong linkage with longterm memory. Valcheva-Kuzmanova et al. [63] assessed the effect of Aronia melanocarpa fruit juice on memory in rats by the PA task and also reported similar findings. The RA test was used to examine WR and CR. Increased number of CRs was used as a parameter to measure the MR compared to the control group. In this study, dosedependent improvement of percentage of MR of EEPEr and EEPEu on 6th and 12th day was used as a measure of learning and memory. To examine the neuroenhancing potentiality of Acacia auriculiformis leaves, Sharma et al. [64] used the RA test and monitored better learning and memory enhancing potentiality in rats. Our results proposed that out of the 2 operative doses of EEPE (i.e., 100 and $200 \mathrm{mg} / \mathrm{kg}$, b.w.), in case of PA test, higher dose of EEPEr (i.e., $200 \mathrm{mg} / \mathrm{kg}$, b.w.), and both lowest and highest doses of EEPEu (i.e., $100 \mathrm{mg}$ and $200 \mathrm{mg} / \mathrm{kg}$, b.w.) and for RA test aforementioned doses of EEPEr and EEPEu fruits improved learning and memory in rats as compared to the control group.

SOD is a group of metalloenzymes, which acts as both antioxidant and anti-inflammatory agent, helps to protect oxygen-metabolizing cells, and repairs cell damage that can be usually done by superoxide free-radicals [65]. Studies revealed that SOD catalyzes to form molecular oxygen $\left(\mathrm{O}_{2}\right)$ and hydrogen peroxide $\left(\mathrm{H}_{2} \mathrm{O}_{2}\right)$ by the breakdown of the superoxide $\left(\mathrm{O}_{2}^{-} \cdot\right)$ radical. This generated $\mathrm{H}_{2} \mathrm{O}_{2}$ can be neutralized by the CAT and glutathione peroxidase systems by converting it to $\mathrm{H}_{2} \mathrm{O}$ and $\mathrm{O}_{2}$, although $\mathrm{H}_{2} \mathrm{O}_{2}$ is less damaging [66]. CAT is a wellknown antioxidant present in all cells responsible for the protection of cells from highly reactive hydroxyl radicals (OH • ) [67]. During normal metabolic processes, $\mathrm{H}_{2} \mathrm{O}_{2}$ is produced as a harmful by-product. To prevent damage to cells by $\mathrm{H}_{2} \mathrm{O}_{2}$, it must be quickly converted into other, less dangerous substances. This function is performed by CAT. It neutralizes the $\mathrm{H}_{2} \mathrm{O}_{2}$ by converting it to $\mathrm{H}_{2} \mathrm{O}$ and $\mathrm{O}_{2}$ [68]. $\mathrm{GSH}$ is an important antioxidant responsible for preventing oxidative damage caused by ROS and providing the first line defense to the body
[69]. Total GSH pool is more than $90 \%$ in healthy cells and tissues. It exerts its function by donating a reducing equivalent to free radicals, peroxides, lipid peroxides, heavy metals, and various electrophilic compounds [70]. GSR and GST are key antioxidant enzymes because they are involved in the reduction of oxidative damage caused by ROS and help in maintaining the reducing environment of the cell [71]. Oxidized glutathione (GSSG) represents less than 10\% of total glutathione. GSR is responsible for the reduction of GSSG to the GSH [72]. GST is considered as primary cellular defense antioxidant that detoxifies ROS. It also catalyzes the nucleophilic attack by GSH on electrophilic substances and consequently prevents oxidative damage [73]. GSH-Px is another main antioxidant enzyme which is responsible for the reduction of $\mathrm{H}_{2} \mathrm{O}_{2}$ to $\mathrm{H}_{2} \mathrm{O}$ by reacting with GSH and converting it to GSSG, which is finally reduced to GSH by GSR [74]. In the progression of neurodegenerative disorder, free radical-mediated lipid peroxidation plays a vital role. TBARS are highly evident in several neurodegenerative diseases, especially AD [75]. In the reduction of oxidative stress and increasing cognition, brain antioxidant enzymes such as SOD, CAT, GSH-Px, GSR, GSH, and GST play a vital role [76]. The study of the effect of aerial parts of Persicaria flaccida on brain antioxidant markers and cognitive performance of rats by Uddin et al. [77] also reported analogous outcomes. Acetylcholine is a neurotransmitter released by nerve cells to send signals to other cells. The cholinergic system (i.e., acetylcholine) is imperative for making memory or encoding, the creation of long-term memory from the new memory or storage and the recall of the memory or recovery [78]. In this study, AChE activity was decreased in both SS and DS portions, with significant effects in rats treated with unripe fruit extract as compared to the control group. Uddin et al. [79] showed that the administration of Phyllanthus acidus fruit increases the brain acetylcholine levels and enhances the cognitive function in rats, while attenuating memory deficits in animal model of amnesia. Our results projected that administration of EEPEr fruit, especially higher dose (i.e., $200 \mathrm{mg} / \mathrm{kg}$ b.w.) and both lowest and highest doses of EEPEu fruit (i.e., $100 \mathrm{mg}$ and $200 \mathrm{mg} /$ $\mathrm{kg}$, b.w.) for 12 days increased the levels of SOD, CAT, GSH-Px, GSR, GSH, GST and decreased the levels of TBARS and AChE activity in rat brain tissue homogenates.

The aforementioned behavioral and biochemical effects suggest that EEPE has the ability to improve cognitive function by the regulation of the antioxidant system. 


\section{Conclusion}

This study clearly demonstrates that EEPE fruits showed marked beneficial effects for improving the learning, memory, and antioxidant potential. Among ripe and unripe fruits, significant cognitive enhancing effects were observed by unripe fruit which is comparable with the standard. Thus, this plant extract can be useful in the treatment of various cognitive disorders, dementia, and neurodegenerative disorders, especially AD. In spite of these findings, further studies are in progress for isolating and identifying promising nootropic compound(s).

\section{Ethical Approval}

The study protocol was approved by the Ethics Committee of the Department of Pharmacy, Southeast University, Dhaka, Bangladesh. The care and use of animals were followed in accordance with the principles of NIH.

\section{Acknowledgements}

The authors wish to thank the Department of Pharmacy, Southeast University, Dhaka, Bangladesh for providing research facilities.

\section{Authors' Contributions}

This work was carried out in collaboration among all authors. M.S.U. and M.A. designed the study, wrote the protocol, managed the analyses of the study, and prepared the draft of the manuscript. M.S.U., A.A.M. and M.S.H. performed the laboratory experiments. F.A. collected and prepared the plant extract and performed literature review. M.A.I. participated in data analysis and interpretation. All authors read and approved the final manuscript.

\section{Disclosure Statement}

The authors proclaim that they have no competing interests.

\section{References}

1 Uddin MS, Mamun AA, Iqbal MA, Islam A, Hossain MF, Khanum S, Rashid M: Analyzing nootropic effect of Phyllanthus reticulatus Poir. on cognitive functions, brain antioxidant enzymes and acetylcholinesterase activity against aluminium-induced Alzheimer's model in rats: applicable for controlling the risk factors of Alzheimer's disease. Adv Alzheimer Dis 2016;5:87-102.

2 Solomon Arunodhayan Sam D, Henri C, Sushmitha, et al: Neuron the memory unit of the brain. J Compu Enginee 2015;17:48-61.

3 Selnes OA, Vinters HV: Vascular cognitive impairment. Nat Clin Pract Neuro 2006;2: 538-547.

4 Chauhan V, Chaudhary A: Alzheimer's disease: a literature review. Eur J Pharma Pand Med Res 2015;2:201-207.

5 Querfurth HW, LaFerla FM: Alzheimer's disease. N Engl J Med 2010;362:329-344.

6 Wimo A, Winblad B, Aguero-Torres H, et al: The magnitude of dementia occurrence in the world. Alzheimer Dis Assoc Disord 2003;17: 63-67.

7 Mamun AA, Uddin MS, Wahid F, Iqbal MA, Rahman MM: Neurodefensive effect of Olea europaea L. in alloxan-induced cognitive dysfunction and brain tissue oxidative stress in mice: incredible natural nootropic. J Neuro Neurosci 2016;7:1.

8 Serrano-Pozo A, Frosch MP, Masliah E, et al: Neuropathological alterations in Alzheimer disease. Cold Spring Harb Perspect Med 2011; 1:a006189.

9 Wray S, Noble W: Linking amyloid and tau pathology in Alzheimer's disease: the role of membrane cholesterol in Abeta-mediated tau toxicity. J Neurosci 2009;29:96659667.

10 Braak H, Braak E: Neuropathological stageing of Alzheimer-related changes. Acta Neuropathol 1991;82:239-259.

11 Kuhla B, Haase C, Flach K, et al: Effect of pseudophosphorylation and cross-linking by lipid peroxidation and advanced glycation end product precursors on tau aggregation and filament formation. J Biol Chem 2007; 282:6984-6991

12 Selley M, Close DR, Stern SE: The effect of increased concentrations of homocysteine on the concentration of (E)-4-hydroxy-2-nonenal in the plasma and cerebrospinal fluid of patients with Alzheimer's disease. Neurobiol Aging 2002;23:383-388.

13 Bradley MA, Markesbery WR, Lovell MA: Increased levels of 4-hydroxynonenal and acrolein in the brain in preclinical Alzheimer disease. Free Radic Biol Med 2010;48:15701576.

14 Sultana R, Butterfield DA: Role of oxidative stress in the progression of Alzheimer's disease. J Alzheimers Dis 2010;19:341-353.

15 Uddin MS, Mamun AA, Khanum S, Begum Y, Alam MS: Analysis of in vitro antioxidant activity of Caryota urens L. leaves: a traditional natural remedy. J Coast Life Med 2016;4:483489.

16 Zhao Y, Zhao B: Oxidative stress and the pathogenesis of Alzheimer's disease. Oxid Med Cell Longev 2013;2013:316523.

17 Agostinho P, Cunha RA, Oliveira C: Neuroinflammation, oxidative stress and the patho- genesis of Alzheimer's disease. Curr Pharm Des 2010;16:2766-2778.

18 Asaduzzaman M, Uddin MJ, Kader MA, et al: In vitro acetylcholinesterase inhibitory activity and the antioxidant properties of Aegle marmelos leaf extract: implications for the treatment of Alzheimer's disease. Psychogeriatrics 2014;14:1-10.

19 Mwitari PG, Ayeka PA, Ondicho J, et al: Antimicrobial activity and probable mechanisms of action of medicinal plants of Kenya: Withania somnifera, Warbugia ugandensis, Prunus Africana and Plectrunthus barbatus. PLoS One 2013;8:e65619.

20 Kayne SB: Traditional Medicine, ed 1. London, Pharmaceutical Press, 2010.

21 Duraipandiyan V, Ayyanar M, Ignacimuthu S: Antimicrobial activity of some ethnomedicinal plants used by Paliyar tribe from Tamil Nadu, India. BMC Complement Altern Med 2006;6:35.

22 Bhattacharjee A, Shashidhara SC, Saha S: Nootropic activity of Crataeva nurvala BuchHam against scopolamine induced cognitive impairment. EXCLI J 2015;14:335-345.

23 Oken BS, Storzbach DM, Kaye JA: The efficacy of Ginkgo biloba on cognitive function in Alzheimer disease. Arch Neurol 1998;55: 1409-14015.

24 Goswami S, Saoji A, Kumar N, et al: Effect of Bacopa monnierion cognitive functions in $\mathrm{Al}$ zheimer's disease patients. Int J Colla Res Int Medi Pub Heal 2011:3:285-289.

25 Skolnick AA: Old Chinese herbal medicine used for fever yields possible new Alzheimer disease therapy. JAMA 1997;277:776. 
26 Zhu X, Wang J, Ou Y, et al: Polyphenol extract of Phyllanthus emblica (PEEP) induces inhibition of cell proliferation and triggers apoptosis in cervical cancer cells. Eur J Med Res 2013;18:46.

27 Hossen Moazzem SM, Sarkar R, Mahmud S, et al: Medicinal potential of Phyllanthus emblica (Linn.) fruits extracts: biological and pharmacological activities. Bri J Pharma Re 2014;4:1486-1499.

28 Krishnaveni M, Mirunalini S: Amla - the role of ayurvedic therapeutic herb in cancer. Asi J Pharma Cli Res 2011;4:13.

29 Zhang YJ, Tanaka T, Iwamoto Y, et al: Phyllaemblic acid, a novel highly oxygenated norbisabolane from the roots of Phyllanthus emblica. Tetrahedron Lett 2000;41:17811784.

30 Perianayagam JB, Sharma SK, Joseph A, et al: Evaluation of anti-pyretic and analgesic activity of Emblica officinalis Gaertn. J Ethnopharmacol 2004;95:83-85.

31 Krishnaveni M, Mirunalini S: Therapeutic potential of Phyllanthus emblica (amla): the ayurvedic wonder. J Basic Clin Physiol Pharmacol 2010;21:93-105.

32 Dasaroju S, Gottumukkala KM: Current trends in the research of Emblica officinalis (Amla): a pharmacological perspective. Int J Pharm Sci Rev Res 2014;24:150.

33 Ihantola-Vormisto A, Summanen J, Kankaanranta $\mathrm{H}$, et al: Anti-inflammatory activity of extracts from leaves of Phyllanthus emblica. Planta Med 1997;63:518-524.

34 Dhale DA, Mogle UP: Phytochemical screening and antibacterial activity of Phyllanthus emblica (L.). Sci Res Reporte 2011;1:138142.

35 Raghu HS, Ravindra P: Antimicrobial activity and phytochemical study of Phyllanthus emblica Linn. Int J Pharma Stud Res 2010;1:3033.

36 Iamsaard S, Arun S, Burawat J, et al: Phenolic contents and antioxidant capacities of ThaiMakham Pom (Phyllanthus emblica L.) aqueous extracts. J Zhejiang Univ Sci B 2014;15: 405-408.

37 Ashwlayan VD, Singh R: Reversal effect of Phyllanthus emblica (euphorbiaceae) rasayana on memory deficits in mice. Int J App Pharmace 2011;3:10-15.

38 National Research Council: Guide for the Care and Use of Laboratory Animals, ed 8. Washington, National Academies Press, 2011.

39 Weon JB, Lee J, Eom MR, et al: The effects of Loranthus parasiticus on scopolamine-induced memory impairment in mice. Evid Based Complement Alternat Med 2014;2014: 860180.

40 Tasanarong A, Kongkham S, Itharat A: Antioxidant effect of Phyllanthus emblica extract prevents contrast-induced acute kidney injury. BMC Complement Altern Med 2014;14: 138.

41 Organisation for Economic Cooperation and Development: OECD Guidelines for the Test- ing of Chemicals: Acute Oral Toxicity - Acute Toxic Class Method. Paris, OECD, 2002.

42 Akar F, Mutlu O, Komsuoglu Celikyurt I, et al: Zaprinast and Rolipram enhances spatial and emotional memory in the elevated plus maze and passive avoidance tests and diminishes exploratory activity in naive mice. Med Sci Monit Basic Res 2014;20:105-111.

43 van der Staay FJ, Schuurman T, van Reenen CG, et al: Emotional reactivity and cognitive performance in aversively motivated tasks: a comparison between four rat strains. Behav Brain Funct 2009;5:50.

44 Wang J, Wang X, Lv B, et al: Effects of Fructus akebiae on learning and memory impairment in a scopolamine-induced animal model of dementia. Exp Ther Med 2014;8:671-675.

45 Morris R: Developments of a water-maze procedure for studying spatial learning in the rat. J Neurosci Methods 1984;11:47-60.

46 Saadipour K, Sarkaki A, Alaei H, et al: Forced exercise improves passive avoidance memory in morphine-exposed rats. Pak J Biol Sci 2009; 12:1206-1211.

47 Benchenane K, Castel H, Boulouard M, et al Anti-NR1 N-terminal-domain vaccination unmasks the crucial action of tPA on NMDAreceptor-mediated toxicity and spatial memory. J Cell Sci 2007;120(pt 4):578-585.

48 Sossin WS, Lacaille JC, Castellucci VF, et al: Progress in Brain Research; Essence of Memory, ed 1. Netherland, Elsevir, 2008.

49 Rao MK, Rao MS, Rao GS: Treatment with Centalla asiatica (Linn) fresh leaf extract enhances learning ability and memory retention power in rats. Neurosciences (Riyadh) 2007; 12:236-241.

50 Deacon RM, Rawlins JN: T-maze alternation in the rodent. Nat Protoc 2006;1:7-12.

51 Kameyama T, Nabeshima T, Kozawa T: Stepdown-type passive avoidance- and escapelearning method. Suitability for experimental amnesia models. J Pharmacol Methods 1986; 16:39-52.

52 Kakkar P, Das B, Viswanathan PN: A modified spectrophotometric assay of superoxide dismutase. Indian J Biochem Biophys 1984; 21:130-132.

53 Chance B, Maehly AC: Assay of catalase and peroxidases. Meth Enzymo 1955;11:764-775.

54 Mohandas J, Marshall JJ, Duggin GG, et al: Differential distribution of glutathione and glutathione-related enzymes in rabbit kidney. Possible implications in analgesic nephropathy. Biochem Pharmacol 1984;33:1801-1807.

55 Bhaskar M, Chintamaneni M: Investigating the role of Eclipta alba on brain antioxidant markers, cognitive performance and acetylcholinesterase activity of rats. Int J Pharm Phytopharmacol Res 2014;3:390-394.

56 Jollow DJ, Mitchell JR, Zampaglione N, et al: Bromobenzene-induced liver necrosis. Protective role of glutathione and evidence for 3,4-bromobenzene oxide as the hepatotoxic metabolite. Pharmacology 1974;11:151-169.

57 Habig WH, Pabst MJ, Jakoby WB: Glutathione S-transferases. The first enzymatic step in mercapturic acid formation. J Biol Chem 1974;249:7130-7139.

58 Iqbal M, Sharma MD, Rezazadeh HR, et al Glutathione metabolizing enzymes and oxidative stress in ferric nitrilotriacetate mediated hepatic injury. Redox Report 1996;2: 385-391.

59 Ellman GL, Courtney KD, Andres V Jr, et al: A new and rapid colorimetric determination of acetylcholinesterase activity. Biochem Pharmacol 1961;7:88-95.

60 Ncube NS, Afolayan AJ, Okoh AI: Assessment techniques of antimicrobial properties of natural compounds of plant origin: current methods and future trends. Afr J Biotechnol 2008;7:1797-1806.

61 Kumar GP, Khanum F: Neuroprotective potential of phytochemicals. Pharmacogn Rev 2012;6:81-90.

62 Gong X, Sucher NJ: Stroke therapy in traditional Chinese medicine (TCM): prospects for drug discovery and development. Trends Pharmacol Sci 1999;20:191-196.

63 Valcheva-Kuzmanova SV, Eftimov MT, Tashev RE, et al: Memory effects of Aronia melanocarpa fruit juice in a passive avoidance test in rats. Folia Med (Plovdiv) 2014;56:199_ 203

64 Sharma A, Shetty M, Parida A, et al: Effect of ethanolic extract of Acacia auriculiformis leaves on learning and memory in rats. Pharmacognosy Res 2014;6:246-250.

65 Salin ML, McCord JM: Free radicals and inflammation. Protection of phagocytosine leukocytes by superoxide dismutase. J Clin Investi 1975;56:1319-1323.

66 Ansari MA, Scheff SW: Oxidative stress in the progression of Alzheimer disease in the frontal cortex. J Neuropathol Exp Neurol 2010;69: 155-167.

67 Celik VK, Ersan E, Ersan S, et al: Plasma catalase, glutathione-S-transferase and total antioxidant activity levels of children with attention deficit and hyperactivity disorder. Adv Biosci Biotech 2013;4:183-187.

68 Fernandez C, San Miguel E, Fernandez-briera A: Superoxide dismutase and catalase: tissue activities and relation with age in the longlived species Margaritifera margaritifera. Biol Res 2009;42:57-68.

69 Yadav P, Sarkar S, Bhatnagar D: Action of Capparis decidua against alloxan-induced oxidative stress and diabetes in rat tissues. Pharmacol Res 1997;36:221-228.

70 Meister A: Glutathione-ascorbic acid antioxidant system in animals. J Biol Chem 1994;269: 9397-9400.

71 Fang YZ, Yang S, Wu G: Free radicals, antioxidants, and nutrition. Nutrition 2002;18: 872-879.

72 Deponte M: Glutathione catalysis and the reaction mechanisms of glutathione-dependent enzymes. Biochim Biophys Acta 2013;1830: 3217-3266.

73 Hayes JD, Flanagan JU, Jowsey IR: Glutathione transferases. Annu Rev Pharmacol Toxicol 2005;45:51-88. 
74 Maritim AC, Sanders RA, Watkins JB 3rd: Effects of alpha-lipoic acid on biomarkers of oxidative stress in streptozotocin-induced diabetic rats. J Nutr Biochem 2003;14:288-294.

75 Galasko D, Montine TJ: Biomarkers of oxidative damage and inflammation in Alzheimer's disease. Biomark Med 2010;4:27-36.

76 El-Missiry MA: Antioxidant enzyme, ed 1. Croatia, InTech, 2012.
77 Uddin MS, Nasrullah M, Hossain MS, Rahman MM, Sarwar MS, Amran MS, et al: Evaluation of nootropic activity of Persicaria flaccida on cognitive performance, brain antioxidant markers and acetylcholinesterase activity in rats: implication for the management of Alzheimer's disease. Ame J Psy Neurosci 2016;4:26-37.

78 McIntyre CK, Pal SN, Marriott LK, et al: Competition between memory systems: acetylcholine release in the hippocampus correlates negatively with good performance on an amygdala-dependent task. J Neurosci 2002; 22:1171-1176.
79 Uddin MS, Mamun AA, Hossain MS, Ashaduzzaman M, Noor Asif MA, Hossain MS, Uddin MJ, Sarker J, Asaduzzaman M: Neuroprotective effect of Phyllanthus acidus L. on learning and memory impairment in scopolamine-induced animal model of dementia and oxidative stress: natural wonder for regulating the development and progression of $\mathrm{Al}$ zheimer's disease. Adv Alzheimer Dis 2016;5: 53-72. 